\title{
Monasterolo, E., y Pittaluga, R. (Eds.) (2017). Formas de la política. Experiencias de activismo en el pasado reciente. Argentina (1969-2010)
}

\author{
Santa Rosa, EdUNLPam, 207 páginas.
}

Valentina Santander ${ }^{1}$

$\mathrm{F}$ ormas de la política. Experiencias de activismo en el pasado reciente. Argentina (1969-2010) editado por Elvio Monasterolo y Roberto Pittaluga, es un libro compuesto por un conjunto de textos heterogéneos que fueron compilados bajo la convocatoria de Libros Académicos de Interés Regional por la Editorial de la Universidad Nacional de La Pampa. Combina producción académica de miembros de esa universidad con escritos provenientes de otras casas de estudio.

La obra recoge recorridos cronológicos, espacios geográficos y problemáticas que son diversas y, en ocasiones, dispares entre sí. La recopilación que exhibe no está pensada para conformar una secuencia lineal o una narrativa del pasado, sino para presentar imágenes. Cada capítulo busca responder a la pregunta directriz del libro: ¿cuáles son las formas de la política? Proponiéndose, en cada sección, ampliar la mirada sobre lo que se entiende por política. Una reflexión que implica indagar sobre diferentes experiencias, incluso aquellas que no fueron pensadas en tales términos por sus propios protagonistas.

Los capítulos se despliegan en tres secciones. La primera aborda la politización de los sectores profesionales e institucionales. Así, nos encontramos con el capítulo de Anahí Huarte y Roberto Pittaluga En torno a la experiencia del Instituto de Estudios Regionales de la UNLPam (1974-1975) que indaga sobre un emprendimiento académico que tuvo un impacto significativo tanto en su época como en los posteriores proyectos que buscaron continuar con sus lineamientos, así como aquellos que se constituyeron 'herederos' de su visión. La investigación se basa en material del Instituto que sobrevivió a su destrucción en el año 1975 y en entrevistas realizadas a antiguos miembros. Trabaja sobre dos instancias: la conformación del Instituto y el Seminario de Historia y Geografía Regional. Respecto a la primera concluye que su proceso de conformación respondió a la necesidad y la voluntad de generar un espacio que aborde las problemáticas regionales pero que a su vez reflexione sobre su conceptualización. En relación al Seminario, el análisis se centró en las concepciones de la historia que se proponían en esta experiencia de puertas abiertas a la comunidad.

$1 \quad$ Integrante del Instituto de Estudios Históricos y Sociales de La Pampa, Facultad de Ciencias Humanas, Universidad Nacional de La Pampa. 
El segundo capítulo Notas sobre la politización de los abogados en los primeros setenta de Mauricio Chama explora sobre los procesos de politización de los abogados en los '60 y '70, particularmente de un sector de abogados porteños que se comprometieron con la defensa legal de los presos políticos, estudiantiles, gremiales, y con la denuncia de la represión estatal y paraestatal. El objetivo del autor es generar un enfoque que reponga "las posiciones de los actores, sus interacciones, las lógicas de sus prácticas y el contenido de sus discursos, intentando captar el sentido que les otorgaban a sus acciones, en el horizonte de los dilemas y tensiones de esa época" (p. 52).

El último capítulo de esta sección es Camellos: literatura y política en Manual de Perdedores, de Juan Sasturain de Damián Repetto. En estas páginas, el autor, se pregunta sobre la posibilidad de visibilizar las percepciones sobre los procesos históricos en los cuales son producidas las obras literarias. El análisis se desarrolla en dos dimensiones que interactúan entre sí: la reflexión en torno a las especificidades del género policial en Latinoamérica y particularmente en Argentina, y el estudio de dos obras del género que permiten poner en juego la escala nacional y regional. Las novelas abordadas son Manual de perdedores, de Juan Saturain y iAy, Masallé! escrita por Juan Carlos Pumilla. A partir de ellas logra evidenciar los 'ligamentos' existentes entre las escalas de análisis y la capacidad de discutir tempranamente dos concepciones vinculadas al terrorismo de Estado; la trama social que posibilitó la represión en el caso de Manual de perdedores, y el accionar represivo en una provincia pequeña que se quiso pensar como una isla, a través de iAy, Masallé!

La segunda sección del libro tiene como eje la militancia. El primer capítulo La política armada. La lógica de las prácticas políticas de las FAR y el problema de la relación con las masas durante los primeros años de la organización de Mora González Canosa². La autora señala un proceso de doble ruptura respecto a la forma de hacer política de los partidos de izquierda en la etapa de formación de las FAR. Por un lado, la separación de los métodos 'legales' de lucha y una nueva concepción del accionar armado que dejaba entrever la persistencia del legado guevarista, a pesar de sus reelaboraciones. La segunda ruptura está vinculada a su visión del peronismo que significó un acercamiento por fuera de las tradiciones liberales. De este doble quiebre deriva la constitución de la organización como político-militar y su identificación con el peronismo. La investigadora traza un cuadro que permite comprender el accionar de las FAR en la coyuntura de los años 1971-72 donde se enfrentaba al desafío de articular su accionar con el resto del movimiento social en un momento donde se perfilaba la apertura electoral y Perón afinaba sus alianzas con sectores que excedían a las juventudes.

El segundo capítulo de esta sección El activismo estudiantil de posdictadura. Franja Morada y la formación de la Corriente Nacional de Liberación. 1983-1987 de Elvio Monasterolo, explora el movimiento estudiantil en la década del '80, particularmente Franja Morada y la conformación de la Corriente Nacional de Liberación (CNL). El autor analiza una práctica política que fue gestada en la intersección de dos procesos; por un lado, la reconfiguración de las tramas sociales después de la dictadura y, por el otro, la creciente desilusión respecto del alfonsinismo. Monasterolo sostiene que la ruptura interna y la consecuente formación del CNL "puede leerse como una 
divergencia de metodologías, prácticas y proyectos políticos" que dieron lugar a una "experiencia coordinadora de grupos locales y/o regionales que erigieron una relativa autonomía, en el plano local, para proyectarse luego en el ámbito nacional" (p. 152). La importancia de este trabajo reside en incorporar miradas que observen las particularidades de una serie de espacios que no suelen ser tenidos en cuenta en la mayoría de las investigaciones que se ocupan del movimiento estudiantil, muchas veces centradas a la Universidad de Buenos Aires y, complementariamente, a la Universidad Nacional de Rosario y la Universidad Nacional de La Plata.

La política de la memoria, es la última sección del libro, recopila dos capítulos que exploran las formas de rememoración del pasado. El primero, titulado Niños apropiados, nietos restituidos. Representaciones, formas de lo político y procesos de construcción de identidad en tres documentales argentinos de Fabricio Laino Sanchis, indaga en los procesos de (re)construcción de las identidades y de elaboración de las memorias de los padres y madres desaparecidos. Para ello, el autor, se sirve de tres documentales: Nietos (identidad y memoria) de Benjamín Ávila (2004), ¿Quién soy? de Estela Bravo (2007) y Victoria de Adrián Jaime (2008). El objetivo es reflexionar sobre las formas de representar el pasado y las problemáticas acerca de la búsqueda y restitución de los niños/as apropiados. Los tres filmes constituyen, desde el punto de vista del investigador, construcciones discursivas que establecen un compromiso ético con la realidad socio-histórica sobre la cual trabajan. En este sentido, las películas están pensadas como un instrumento de intervención sociopolítica que busca legitimar socialmente el reclamo de la organización Abuelas de Plaza de Mayo, alcanzar un público mayor y propiciar el acercamiento de aquellos que dudan de su identidad (p. 178).

De las historias y memorias de la rebeldía. En torno a un audiovisual por los 40 años de la nacionalización de la UNLPam de Elvio Monasterolo y Roberto Pittaluga, es el último capítulo del libro. A través de sus páginas examina la representación del pasado que discurre en el documental Tiempos de rebeldía, la lucha por la nacionalización, analizando los gestos al pasado, a la vez que se los articula con un relato historiográfico sobre el periodo abordado, 1971-73. Los autores entienden esta producción audiovisual como un acto rememorativo que, como tal, guarda una dimensión política en tanto supone el esfuerzo articulado de una serie de actores e instituciones para generar un contenido que permita volver la mirada hacia el pasado. El análisis se centra en el gesto de una fotografía. La trama se dispara a partir del encuentro de los estudiantes con esa fotografía y finaliza cuando ellos, junto a otros miembros de la comunidad universitaria, repiten la escena. Monasterolo y Pittaluga sostienen que "al recrear aquella 'toma fotográfica', los realizadores del audiovisual renuevan el gesto de erguirse pero a la vez exponen que el colectivo intergeneracional que recoge la bandera debió ser forjado a través de este acto de memoria que es el video" (p. 205). Esta intervención en la imagen, ese collage entre pasado y presente, permite dilucidar no sólo como el pasado es representado sino también como el presente se representa en el pasado.

Como eje común, todos los capítulos de este libro conducen a reflexionar sobre las representaciones. Permiten una exploración a través de una pluralidad de subjetivaciones que nos remiten, en toda ocasión, al esfuerzo de comprender cómo cada actor concibió sus prácticas y el vínculo con su tiempo. De esta manera, el libro 
cumple su objetivo de avanzar sobre una comprensión más profunda de la 'experiencia política' entendida esta de forma amplia.

Fecha de recepción: 03/12/2018

Fecha de aceptación: 01/11/2019 